\title{
Potential geo-ecological impacts of the proposed Danube-Oder-Elbe Canal on alluvial landscapes in the Czech Republic
}

\author{
Ivo MACHAR ${ }^{\text {a * }}$, Karel KIRCHNER ${ }^{\text {b }}$, Vilém PECHANEC ${ }^{\text {c }}$, Jan BRUS ${ }^{\text {d }}$, Helena KILIÁNOVÁ ${ }^{\text {, }}$ \\ Lubomír ŠÁLEK ${ }^{\mathrm{d}}$, Antonín BUČEK e
}

\begin{abstract}
The project of a canal connecting the three major Central European Rivers: the Danube, Oder and Elbe, is incorporated into a planned trans-European transport network system. Geographically, the course of the planned canal stretches into the territory of four Central European countries, predominantly that of the Czech Republic. The environmental impacts of the potential construction and operation of the Danube-Oder-Elbe (DOE) Canal is currently widely discussed by experts from various fields. This paper aims to assess some potential impacts of the canal on the alluvial landscapes in the Czech Republic. The method of geo-ecological assessment presented here applies GIS analyses at the larger landscape scale. The results of the geo-ecological assessment of potential impacts of the DOE Canal on the land-use of river floodplains, the fluvial dynamics of streams and the extent of their alluvial plains, and the quantified DOE Canal impact on protected areas and groundwater sources, are presented. The hydrological impact of the DOE Canal will affect a total of 1,975.4 $\mathrm{km}^{2}$ of river basins in the Czech Republic. The DOE Canal will affect 157 sites significant from the perspective of landscape and nature conservation, 7 nature parks and 113 existing water points which are used as groundwater sources. The results show that the most significant disruption of fluvial dynamics of the stream sediment regime would occur in the Protected Landscape Area of Litovelské Pomoravi. In general, the geoecological impact of the DOE Canal on the landscape will be very important.
\end{abstract}

Keywords: Geo-ecological assessment, GIS analysis, hydrological impact, protected areas, floodplain forests, DOE Canal, river floodplain, alluvial plain, Czech Republic

\section{Introduction}

The project of a canal connecting the three largest Central European rivers - the Danube, Oder (Odra) and Elbe (Labe) (hereinafter the DOE Canal) - presents a long-term risk to land use in the wide river floodplains in the Czech Republic (Buček and Machar, 2012). Both the extent of the expected impact on the landscape and the estimated investment costs of the DOE Canal, make it unprecedented in the Central European context (Tournaye et al., 2010).

The first serious proposal for a waterway connecting the Danube and Morava with the Oder, Vistula and Elbe Rivers was published in a Latin treatise by Lothar de Vogemont in Vienna in 1700 (Bartoš, 2004). The intention to build a canal connecting the Danube, Oder and Elbe was mentioned in the first Austrian Water Act of 1869 and the Moravian Provincial Water Act of 1870. Ing. Podhagský designed a project for the canalization of the Morava River at the request of the Moravian Province Committee in 1877. A complex project for the Morava river canalization, including a plan of connecting the Danube and the Oder, was presented by Provincial Building Councillor Ing. T. Nosek in 1882 (Nožička, 1957). In 1901, the Imperial
Council in Vienna passed the Austro-Hungarian Waterway Act. Following its enactment, a canal was to be built between the Danube and the Oder, together with a navigation channel connecting it with the Elbe. In addition, a canal between the Danube and the Moldau (Vltava) was to be built near České Budějovice, together with a navigation channel between the Danube-Oder canal and the Vistula River and further as far as the navigable section of the Dniester River.

In 1931, the Czechoslovak Republic adopted a new Waterway Act. At that time the total costs of the DOE construction were estimated at three billion crowns. The construction was to take place in two six-year stages. During the first stage, the Danube-Oder canal was to be built, to be connected to the Elbe in the second stage of the construction. Nazi Germany decided to situate the main Danube port of the DOE Canal near Vienna. Between 1938 and 1943, three canal sections were built in Lobau on the eastern edge of Vienna, using concentration camp prisoners as labourers. In the long history of the proposed canal, these 9 kilometres represent the only section of the Danube-Oder-Elbe Canal constructed to date (Petrášová and Machalíková, 2013).

\footnotetext{
${ }^{a}$ Dpt. of Development Studies, Faculty of Science, Palacký University Olomouc, Olomouc, Czech Republic (*corresponding author:Ivo Machar, e-mail: ivo.machar@upol.cz)

${ }^{\mathrm{b}}$ Institute of Geonics of the Czech Academy of Sciences v.v.i., Dpt. of Environmental Geography, Brno, Czech Republic

${ }^{\mathrm{c}}$ Dpt. of Geoinformatics, Faculty of Science, Palacký University Olomouc, Olomouc, Czech Republic

${ }^{d}$ Dpt. of Forest Management, Faculty of Forestry and Wood Sciences, Czech University of Life Sciences, Praha, Czech Republic

${ }^{\text {e }}$ Dpt. of Forest Botany, Dendrology and Geobiocoenology, Faculty of Forestry and Wood Technology, Mendel University in Brno, Brno, Czech Republic
} 
In 1966-1968, a General Solution of the Danube-OderElbe Canal Interconnection was produced, representing the most comprehensive and detailed design of the DOE Canal to date (Buček, 2005). The course of the canal was designed at 1:10 000 scale, with longitudinal profiles and blueprints of the main facilities. The General Solution served as the principal document for Government Decree No. 167/1971 and Presidium Decree No. 299/1972. These decrees, which are no longer valid, stipulated the protection of the future course of the DOE Canal in territorial plans of all levels. At present, the course of the DOE Canal is incorporated in several regional spatial planning strategies (the so-called Development Principles) and is part of the spatial planning documentation of a number of municipalities. The national concept of spatial planning in the Czech Republic (Spatial development policy of the $\mathrm{CR}$ ) advises further examination of the DOE project (Machar, 2012).

The corridor of the planned DOE Canal in the Czech Republic includes wide river floodplains of eight biogeographical regions, within all four biogeographical sub-provinces of the Czech Republic (sensu Culek, 1996). The potential impact of the DOE Canal on the landscape of the Czech Republic has been subject to scientific research and assessment only in the past two decades (Buček and Kř́iž, 1989; Vlček, 1992).

The Gabčíkovo water reservoirs constructed on the Danube offer a partial geo-ecological analogy, albeit on a much lesser extent, to the situation which would arise after the completion of construction of the DOE Canal in the floodplains of large Central European Rivers (Zinke, 2002).

This paper deals with some of the potential geo-ecological impacts of the DOE Canal on the landscape of large lowland river floodplains in the Czech Republic, which can be assessed in a GIS environment. It focuses particularly on the potential impact of the DOE Canal on the land-use of river floodplains, the fluvial dynamics of streams and the extent of their alluvial plains, and it quantifies the DOE Canal impact on protected areas and groundwater sources.
At present, the DOE Canal project is subject to political and, in particular, expert discussions, both in the Czech Republic and in the neighbouring states. These discussions should be based on scientific evidence. The present paper contributes to the discussions of potential impacts of the DOE project on the biodiversity and ecosystem functions of the Central European lowland alluvial landscape.

\section{Study area}

The DOE Canal project encompasses plans to build an artificial waterway of international importance which is incorporated into the Trans-European Transport Network ("Ten-T": European Commission, 2003). The route of the planned canal lies in the territory of five European countries - Czech Republic, Slovak Republic, Austria, Germany and Poland (Fig. 1). For the purposes of this paper, the defined study area encompasses the area of the Morava, Elbe (Labe) and Oder (Odra) River basins in the Czech Republic.

\section{Material and methods}

The analyses are based on the DOE Canal route designed in the General Solution of the Danube-Oder-Elbe Canal Interconnection (Hydroprojekt, 1968), adjusted to meet the specifications of current Development Principles of individual Czech regions. The DOE Canal route was digitized using ARC GIS 8.2 on maps of scale 1:10 000. The digitization and related GIS analyses were conducted in the period 2003-2005 (Obrdlík and Machar, 2005).

The technical parameters of the DOE Canal in the Czech Republic were adopted from a paper by Kubec (2002): a manmade canal of an average surface width of $60 \mathrm{~m}$, with a yearround guaranteed minimum draft of $280 \mathrm{~cm}$, suitable for cargo ships of $11.4 \mathrm{~m}$ in width, $110 \mathrm{~m}$ in length and 2,500 t tonnage, and for tug boats of $185 \mathrm{~m}$ in length. The highest elevation in the Oder branch is $285 \mathrm{~m}$ above sea level, in the Elbe branch $395 \mathrm{~m}$. These elevations are to be reached

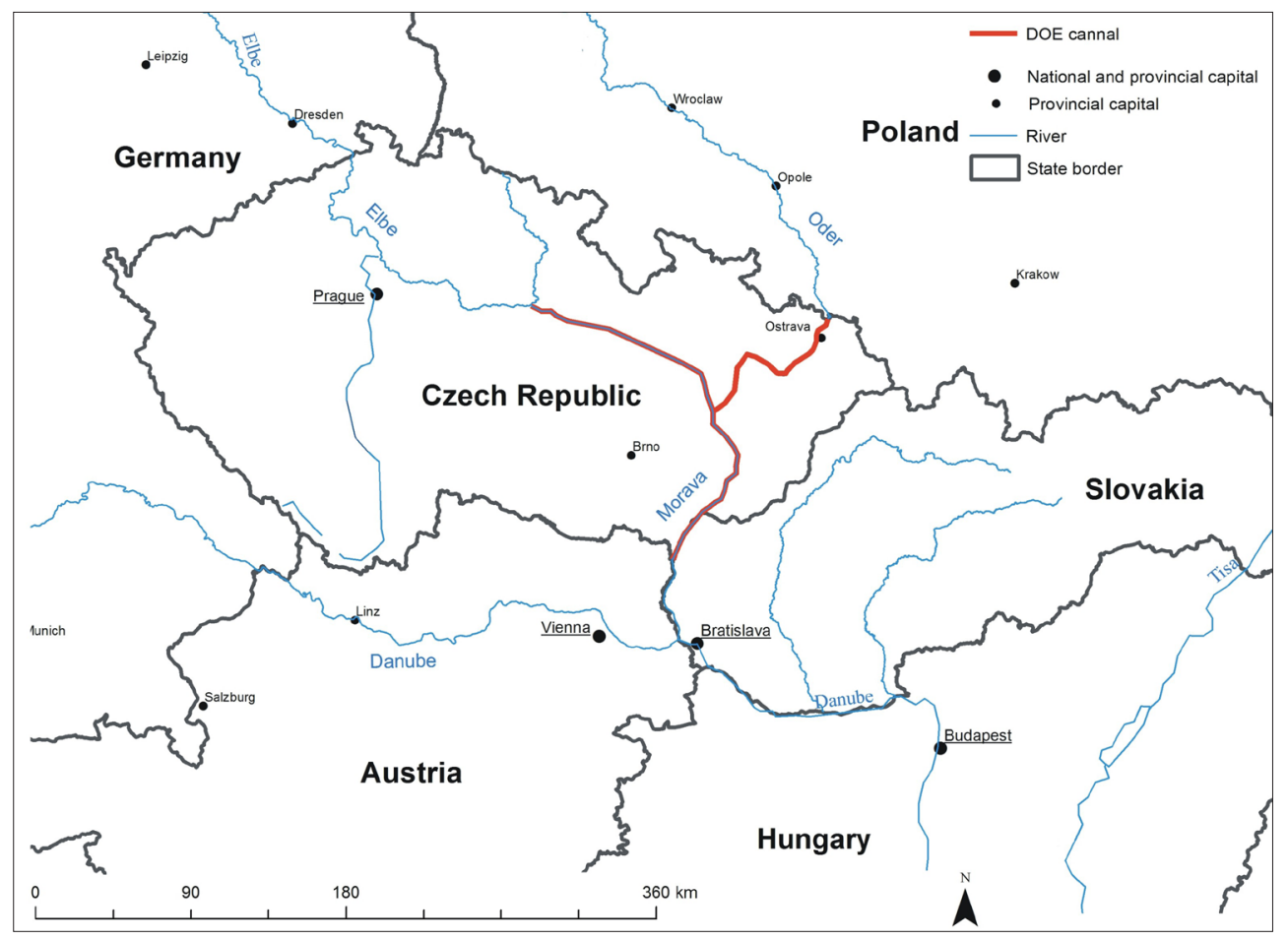

Fig. 1: Project of the DOE Canal in Central Europe - general situation. Source: authors' elaboration 
through the construction of lock chambers with a minimum width of $12.5 \mathrm{~m}$. The route of the canal is to incorporate a number of locks and dams (Kubec and Podzimek, 1988).

After reduction to scale 1:10 000, the digitized route of the DOE Canal was overlain on the digital version of the Basic Water Management Map of the Czech Republic, to locate the points where the DOE Canal route crosses watercourses in the Morava, Oder and Elbe river basins. The GIS analysis enabled categorization of watercourses according to the type of crossing with the route of the DOE Canal (see Tab. 2). The technical solution of the DOE Canal envisages two possibilities of a watercourse crossing the canal: the watercourse is either channelled under the canal body through an artificial conduit or it opens straight into the DOE Canal, thus providing water for the canal.

Watercourses opening into the canal will therefore be deprived of a certain (probably significant) part of their discharges in their sections downstream of the canal crossing. The area of the river basin which is drained by such a stream prior to the construction of the DOE Canal will therefore be subject to hydrological impact after the canal construction. This hydrological impact will be caused by the impoverishment of the water, which will supply the canal (from watercourses opening into the canal).The resulting impact on the entire basin of the affected stream is then expressed by the ratio between the hydrologicallyaffected area of the basin to the area of the entire basin of the stream. Experts consider values exceeding $60 \%$ to be a highly significant hydrological impact on a river basin (Jones and Mulholand, 2000).

In the following step, the area of floodplains subject to hydrological impact of the DOE Canal was identified by GIS analysis. This was carried out by overlaying the areas of affected basins with the areas of inundation (flood) plains, adopted from the Basic Water Management Map and specified within the land-use plans of individual settlements, including the current changes in the definition of flood areas at the time of conducting the GIS analysis in 2005 .

By overlaying the areas of floodplains subject to hydrological impact with the vector layer of boundaries of specially protected areas valid in 2005, the GIS analysis identified areas important in terms of nature and landscape conservation, which will be affected hydrologically by the DOE Canal.

The impact of the DOE Canal on groundwater supplies was analysed in a similar manner by overlaying the canal route with hydrologically affected inundation plains.
To obtain information about the current land cover along the route of the DOE Canal, a digital CORINE map with the projected digitized DOE Canal route was used (Pechanec, 2012). This data layer was then applied in a preliminary analysis of the DOE impact on dominant fluvial processes, which condition the dynamics of the fluvial succession series of floodplain biotopes (Machar and Pechanec, 2011). A digital layer of landscape types according to the relative altitudinal zonation (Demek and Mackovčin, 2006) was used for the basic identification of dominant fluvial processes (Rosgen, 1996) in the river basins of the study area. Based on the overlays of river basin areas and altitudinal zonation, river basin types according to the dominant fluvial dynamics were identified. An overlay with the digitized canal route enabled a preliminary assessment of the potential impact of the canal on the dynamics of the fluvial processes in these alluvial landscapes.

In 2012-2013 the GIS analyses were complemented by preliminary field research in the study area. The field research focused on recording sites significant from the perspective of nature and landscape conservation, and which are at the same time potentially subject to impact on their streams' hydrologic and sediment regimes after the DOE Canal construction. A total of 338 sites were recorded in the course of the field research, during which a total of 1,560 jpg images were taken. The locations of individual recorded sites were then digitized and interlinked with the individual images in a GIS project, which enables their location and interactive viewing.

\section{Results}

The digitized route of the DOE Canal within the territory of the Czech Republic measures a total length of $418.1 \mathrm{~km}$, with $44.6 \%$ in the Elbe River basin $(186.4 \mathrm{~km}), 24.8 \%$ in the Oder River basin (103.6 km), and $30.6 \%$ in the Morava River basin $(128.1 \mathrm{~km})$.

The GIS analysis of watercourse categorization according to the type of crossing of the route of the DOE Canal (Tab. 1), shows that most watercourses (i.e. $1,650.6 \mathrm{~km}$ ) are to be channelled into the canal (i.e. $83 \%$ of the total length of watercourses crossing the canal). Only $17 \%$ of watercourses are to be channelled under the canal body through a conduit (the discharge regime of these watercourses will therefore not be affected by the canal). From the environmental perspective it is significant that $19 \%$ of the total length of watercourses (i.e. $382.4 \mathrm{~km}$ ) will be affected by discharge deprivation due to water channelled into the canal.

\begin{tabular}{|l|c|c|}
\hline \multicolumn{1}{|c|}{ Categories of watercourse sections based on the DOE impact } & Section & Length (km) \\
\hline $\begin{array}{l}\text { Watercourse sections between opening to the DOE Canal } \\
\text { and opening to a higher-order stream }\end{array}$ & A & 382.4 \\
Watercourses opening to the DOE Canal (watercourse water is utilized) & B & 654.4 \\
Watercourses opening into streams opening into the DOE Canal & $\mathrm{C}$ & 621.9 \\
$\begin{array}{l}\text { Watercourse sections between the conduit under the DOE Canal } \\
\text { and opening into a higher-order stream }\end{array}$ & $\mathrm{D}$ & 16.2 \\
Watercourses opening into the conduit under the DOE Canal & $\mathrm{E}$ & 79.4 \\
$\begin{array}{l}\text { Watercourses opening into watercourses opening } \\
\text { into the conduit under the DOE Canal }\end{array}$ & $\mathrm{F}$ & 234.4 \\
\hline TOTAL & & $1,988.7 \mathrm{~km}$ \\
\hline
\end{tabular}

Tab. 1: Classification of watercourses in the Czech Republic based on the type of crossing with the DOE Canal Source: authors 
The hydrological impact of the DOE Canal will affect a total of $1,975.4 \mathrm{~km}^{2}$ of river basins in the Czech Republic (Tab. 2). A total of $629.6 \mathrm{~km}^{2}$ of river basins will be subject to significant hydrological impact (over 60\%, see Material and methods, above) caused by the DOE Canal.

The area of alluvial plains potentially subject to hydrological impact (see the section on Material and methods) of the DOE Canal in the Czech Republic is $682.02 \mathrm{~km}^{2}$. Approximately half of this area (48\%) will be subject to a very significant (over 60\%) hydrological impact (Tab. 3).

The sites which will be highly affected include mainly segments of the alluvial landscape in the Morava River basin: Litovelské Pomoraví - $52.8 \mathrm{~km}^{2}$ (Fig. 2, cover p. 2), floodplain at the confluence of the Morava and Bečva Rivers $-147.4 \mathrm{~km}^{2}$, the Morava River floodplain at Uherské Hradiště $-7.9 \mathrm{~km}^{2}$, the Morava River floodplain between Rohatec and the Dyje River confluence - $116.5 \mathrm{~km}^{2}$, floodplain of the Třebůvka River $-1.2 \mathrm{~km}^{2}$, and the floodplain at the confluence of the Oder and Olše Rivers in the Oder River basin $-3.0 \mathrm{~km}^{2}$ (Fig. 3).

The DOE Canal will hydrologically affect $188.1 \mathrm{~km}^{2}$ of sites significant from the perspective of landscape and nature conservation (157 sites, see Tab. 4). 35 specially protected areas (covering a total of $14.7 \mathrm{~km}^{2}$ ) will be affected by the direct loss of land due to the canal construction $(60 \mathrm{~m}$ canal width, plus a 100-metre-wide canal construction site and canal embankment).
The DOE route runs across seven nature parks (Tab. 4), whose role is to protect the preserved landscape character (Löw and Míchal, 2003). The construction of the DOE Canal as a line transportation route could radically change the landscape character of these sites.

The DOE route in the study area would directly affect 113 existing water points which are used as groundwater sources. A total of 346 groundwater sources are situated in the area potentially impacted by the DOE Canal. Impact on the natural groundwater flow caused by the canal construction cannot be ruled out in these water resources.

The current land uses along the planned DOE route are shown in Tab. 5. The dominant land-use forms around the DOE route are farming $(55.7 \%)$ and nature conservation $(27.4 \%)$, while human settlements account for only $2.3 \%$.

Preliminary information on the potential impacts of the DOE Canal on the fluvial sediment dynamics of streams in the study area is provided in Tab. 6. Sediment sources of the study area streams fall predominantly within the areas of the Hrubý Jeseník, Nízký Jeseník and Beskydy Mts. The GIS analysis identified streams whose sediment transport from the source areas will be disrupted by the DOE Canal. The results shown the most significant disruption of fluvial dynamics of the stream sediment regime will occur in the Protected Landscape Area of Litovelské Pomoraví (Fig. 4, see cover p. 2). The disruption of fluvial dynamics of the stream

\begin{tabular}{|c|c|c|}
\hline \multirow{2}{*}{$\begin{array}{c}\text { Hydrological impact } \\
(\%)\end{array}$} & \multicolumn{2}{|c|}{ Area of river basins subject to hydrological impact } \\
\cline { 2 - 3 } & $\mathrm{km}^{2}$ & $\%$ \\
\hline $0.001-10$ & 678.54 & 34.4 \\
$10.001-20$ & 288.52 & 14.6 \\
$20.001-30$ & 202.83 & 10.3 \\
$30.001-40$ & 16.07 & 0.8 \\
$40.001-50$ & 38.89 & 2.0 \\
$50.001-60$ & 116.24 & 5.9 \\
$60.001-70$ & 4.77 & 0.2 \\
$70.001-80$ & 165.85 & 8.3 \\
$80.001-90$ & 28.26 & 1.4 \\
$90.001-100$ & 435.46 & 22.1 \\
\hline TOTAL & $1,975.43$ & 100.0 \\
\hline
\end{tabular}

Tab. 2: Hydrological impact on river basins in the Czech Republic after the construction of the DOE Canal Source: authors

\begin{tabular}{|c|c|c|}
\hline $\begin{array}{l}\text { Alluvial landscapes subject } \\
\text { to significant DOE impact }\end{array}$ & $\begin{array}{l}\text { Area of alluvial landscape } \\
\qquad\left(\mathbf{k m}^{2}\right)\end{array}$ & $\begin{array}{l}\text { Hydrological impact } \\
(\%)\end{array}$ \\
\hline Morava River floodplain above Olomouc & 52.83 & 80.8 \\
\hline $\begin{array}{l}\text { Morava River floodplain below Olomouc, confluence } \\
\text { with the Bečva River }\end{array}$ & 147.37 & 72.2 \\
\hline Morava River floodplain above Uherské Hradiště & 7.92 & 93.9 \\
\hline $\begin{array}{l}\text { Morava River floodplain below Rohatec, confluence } \\
\text { with the Dyje River }\end{array}$ & 116.52 & 78.8 \\
\hline Meanders of the Oder, confluence with the Olše River & 3.03 & 72.2 \\
\hline Třebovka River floodplain & 1.25 & 70.3 \\
\hline
\end{tabular}

Tab. 3: Hydrological impact on inundation areas in the Czech Republic after the DOE Canal construction Source: authors 


\begin{tabular}{|l|c|}
\hline \multicolumn{1}{|c|}{ Category } & Number \\
\hline Small-scale protected areas & 94 \\
Large-scale protected areas & 4 \\
Nature parks & 7 \\
Sites of European importance & 47 \\
Bird areas & 5 \\
\hline TOTAL & 157 \\
\hline
\end{tabular}

Tab. 4: Protected Areas and Nature parks in the Czech Republic subject to hydrological impact by the DOE construction. Source: authors sediment regime in the area would trigger gradual ecosystem changes in fluvisoil pedogenesis (Kulhavý and Sáňka, 2009), as well as in the river-bed forming processes within the anastomosed river system (Kirchner and Ivan, 1999).

\section{Discussion}

This paper outlines a relatively wide range of GIS analysis applications (Burrough and McDonnel, 1998) in the assessment of the expected DOE impact on the hydrological regime of the landscape. GIS analysis may objectify the expected DOE impacts on the landscape to a greater degree than has been achieved in other available landscapeecological assessments to date (e.g. Hasik, 2008). The type

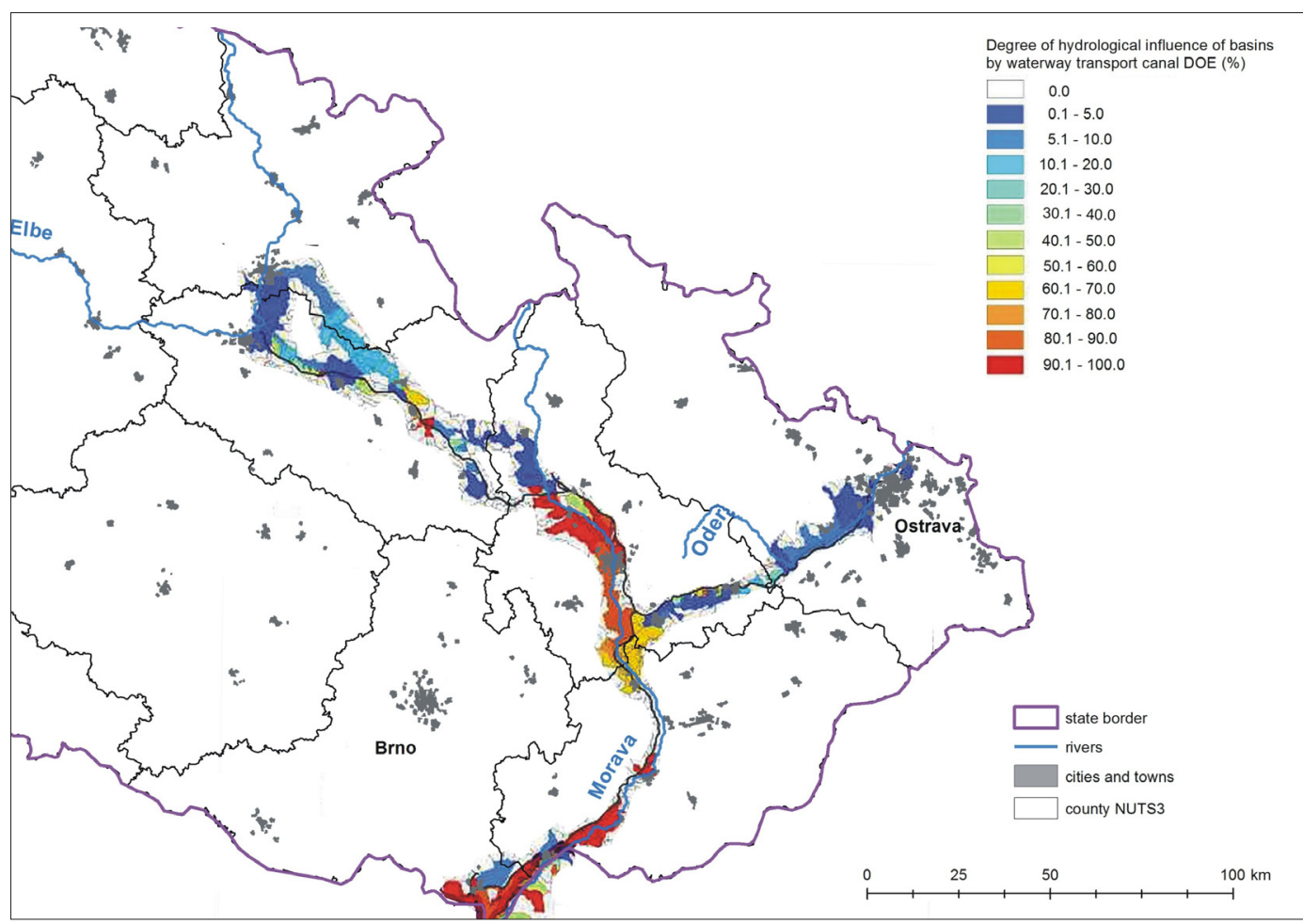

Fig. 3: Alluvial landscapes in the Czech Republic subject to significant hydrological impact of the DOE Canal project Source: authors' elaboration

\begin{tabular}{|l|c|c|}
\hline \multicolumn{1}{|c|}{ Dominant land use along the DOE route } & Length $(\mathbf{k m})$ & Proportion (\%) \\
\hline Built-up areas & 9.84 & 2.33 \\
\hline Forest management, except for nature protection areas & 20.92 & 5.01 \\
\hline Nature and landscape protection & 114.79 & 27.44 \\
\hline Watercourses & 39.74 & 9.52 \\
\hline Farmland & 232.81 & 55.70 \\
\hline
\end{tabular}

Tab. 5: Land use along the DOE route in the Czech Republic. Source: authors

\begin{tabular}{|l|c|c|}
\hline \multicolumn{1}{|c|}{ Dominant fluvial processes in the river basins } & Basin area $\left.\mathbf{( k m}^{\mathbf{2}}\right)$ & Proportion (\%) \\
\hline Basins with dominant erosion processes (mountain areas) & $2,102.95$ & 7.15 \\
\hline Basins with erosion and transport processes (upland areas) & $9,660.82$ & 32.83 \\
\hline Basins with transport and accumulation processes (hilly areas) & $14,271.50$ & 48.50 \\
\hline $\begin{array}{l}\text { Basins with dominant accumulation processes } \\
\text { (lowlands, flatlands, plateaux) }\end{array}$ & $3,389.79$ & 11.52 \\
\hline
\end{tabular}

Tab. 6: Proportion of dominant fluvial processes in river basins in the Czech Republic subject to hydrological impact of the DOE Canal. Source: authors 
of GIS analysis used in this research has been increasingly applied in the process of strategic environmental assessments of investment project impacts on the landscape (Fischer, 2007). GIS applications support environmental analysis of the cumulative impacts of investment projects on the landscape, and applications in the frame of landscape planning (Kolejka and Pokorný, 2000; Sklenička, 2003).

The GIS analysis indicates that the construction and operation of the DOE Canal will trigger changes in the discharge conditions in 19\% of the total length of all watercourses crossing the canal body in the landscape. These watercourses can provide their water to the canal. In order to safeguard a stable depth in the canal, discharges in these water courses will probably be permanently decreased and, moreover, the decreased discharges will fluctuate throughout the navigation season to meet the requirements of the canal. The DOE Canal will therefore affect the ecosystem functions (Pithart and Křováková, 2012) of at least $382.4 \mathrm{~km}$ of waterways. In this context, minimum ecological discharges will need to be maintained in the affected streams, which may pose problems particularly in small watercourses (Macklin and Lewin, 1997). Water which will be available for discharging out of the canal to improve or maintain the minimum discharges of the streams, will probably have altered physical and chemical properties due to its stagnation in the canal bed - it may be assumed that in the summer months the canal water will be warmer than water in the surrounding streams, it may contain increased concentrations of nutrients, etc. (Valett et al., 2014). Water discharged from the canal to the streams may have a significant impact on oxygen conditions, the self-purification capacity and eutrophication of the river ecosystems (Bridge, 2003).

Strategic environmental assessments of large investment projects (similar to the DOE Canal) in EU countries (Glasson et al., 2005) accentuate, among other things, the principles of the European Landscape Convention (Salašová, 2012) promoting an ecosystem approach (Yafee, 1999). The latter finds its optimum application at the landscape scale of river basins (Eiseltová and Biggs, 1995). Based on the GIS analysis, the DOE Canal may hydrologically impact a total of nearly $2,000 \mathrm{~km}^{2}$ of river basins in the Czech Republic. The DOE Canal construction and its hydrological impact on the respective inundation areas may conflict with the concept of river landscape restoration (Molen and Buijse, 2007), which encompasses the issue of restoring the water retention capacity of river landscapes (Štěrba, 2008), drawing on the principles of close-to-nature flood control measures which have been widely discussed in relation to climate change and the related adaptation measures (Bren, 1993).

According to the GIS analysis, the DOE Canal will significantly affect a total of 157 sites for nature and landscape protection. The GIS analysis yields only approximate information, as the construction and operation of the canal may affect these sites in a different ways and with different intensity, depending on the subject of protection and the type of habitats in a given site (Roth, 2003). Some of these sites belong to the Natura 2000 network. A special legislative regime of assessing investment project impacts on species and habitats of European importance is valid for the sites within the Natura 2000 network (European Communities, 2002). This special assessment of the DOE project to Natura 2000 sites should be applied in the future.

Using a method of evaluating habitats of European importance and GIS analysis, Machar (2010a) determined the ecological damage caused by the DOE Canal construction amounting to 1.043 billion points (Seják and Pokorný, 2008). When considering the current point value $(15.88 \mathrm{CZK} /$ point in 2013), this represents a loss of CZK 16.5 billion. The annual loss in the most vulnerable regulation and supporting ecosystem services in the landscape of the Czech Republic, due to the DOE Canal construction, as estimated by the Environmental Committee of the Academy of Sciences of the Czech Republic using the energy-watervegetation-based method, amounts to tens of billions Czech crowns (Šrám, 2014).

Nature parks, designated with the primary objective to protect landscape character, may be affected both by the DOE Canal construction itself and by the set of canalrelated investment projects (high bridges, percolation channels, rerouting of roads, etc.). The DOE Canal would in all probability significantly affect the landscape character of the Morava, Oder and Elbe River floodplains in the entire study area.

The results of land-use analysis of areas lying in the proposed route of the DOE Canal have shown that, in line with the well-known land use in the Czech Republic (Bičík et al. 2010), utilized agricultural area represents the dominant land-use type in the affected floodplains. The second most widespread land-use form in the DOE Canal route is the area used for the purposes of nature and landscape protection (Tab. 4), which is highly relevant information for the environmental assessment of the DOE project. The fact that the DOE Canal may affect a significant part of protected areas tends to be one of the key arguments used by opponents of the DOE Canal project (Štěrba, 2004).

The GIS analysis can provide only preliminary information about the potential impact of the DOE Canal on the natural groundwater flow in the floodplains of the study area. Therefore, the analysis presented in this paper focused only on point groundwater sources. The aim of this analysis is to draw attention to the potential problems related to water sources in the area, which might be subject to hydrological impact of the DOE Canal, as part of the discussion about the possible consequences of climate change on water sources within the floodplains of large Central European rivers (Dvořák et al., 1997). The river alluvium of a watershed is the landscape-ecological backbone of a given catchment area (Haslam, 2008). The GIS analysis of the DOE project presented in this paper shows different degrees of impact on river alluvia in the Czech Republic, indicating that the key areas of ecological networks (Jongman, 1995) are among the most hydrologically affected segments of floodplain landscapes (Tab. 3). Floodplain forests represent one of the key ecosystems of the alluvial landscape (Klimo and Hager, 2001), as they act as important biota refuges in Central European cultural landscapes and enhance the ecological functions of lowland rivers as supra-regional bio-corridors. A study analysing the DOE project impact on the floodplain forest ecosystems in the Czech Republic (Machar, 2010b) showed that most floodplain forest geobiocenoses in the inundation plains of the Czech river alluvia would be subject to significant hydrological impact.

The hierarchical level of beta-diversity (Plesník, 2012) is important for the biodiversity of floodplain forests along lowland rivers (Klimo et al., 2008). The fluvial dynamics in European temperate zone floodplains, however, is radically influenced by anthropogenic landscape use, as it falls within the prehistoric oikumena, i.e., the zone of prehistoric settlements from the Neolithic to the present (Poláček, 1999). Within the Central European landscape, sites with preserved 
fluvial dynamics are very rare (Pedroli, 1999). Seen from the environmental perspective, the results of the GIS analysis identifying significant impacts of the DOE Canal on such areas in the Czech Republic (e.g. Litovelské Pomoraví, see Tab. 3) are therefore controversial.

The main problem identified by the GIS analysis comes in the form of the crossing between the Morava River and the canal, which envisages opening the river into the canal. An alternative, a theoretically possible technical solution of the crossing between the Morava River main stream and its branches and the canal (e.g. canal crossing the Morava floodplain via a suspension bridge), would necessitate a solution to deal with an over $100 \mathrm{~m}$ altitudinal difference in the canal level in the vicinity of Králová by Litovel. Some of the latest canal studies envisage a ship lift solution.

In the frame of assessing the DOE Canal impacts on floodplain habitats, the primary focus is on vegetation response to changes in the soil moisture regime (Maděra, 2001). In the past, the soil moisture regime in floodplain forests on river alluvia in the Czech Republic has undergone a number of dramatic changes caused by anthropogenic factors. Probably the most exact data related to this issue were obtained in the course of long-term detailed ecosystem research of the South Moravian Dyje River floodplain, conducted under the international Man and the Biosphere programme (Penka et al., 1985), the results of which may be used as a reference framework for assessing the anthropogenic impact on analogous river floodplain ecosystems. This is due to the fact that the first research stage took place at a time when the natural soil moisture regime, influenced by regular inundations from the natural channel of the Dyje River, still existed in the floodplain forests, while the second stage monitored the conditions and behaviour of the ecosystem under the impact of drastic water-management measures carried out on the Dyje River. Water-management-induced impact on recent soil processes in the floodplain forest ecosystem resulted in a decrease in the gravitational and capillary water content in the rhizosphere and an increase in the aeration of upper soil layers (Penka et al., 1991). The termination of floodplain forest inundations, with their regular production and deposition of sediments, had therefore changed not only the soil moisture regime but also the nutrient cycle and the specific pedogenetic process of humus horizon formation (Prax et al., 2008). Hydrotechnical measures taken in the alluvial landscape, which result in a drop in groundwater levels and elimination of floods, significantly decrease the biodiversity of floodplain forest communities (Štěrba et al., 2000).

A certain analogy for the planned construction of the DOE Canal in the Central European geographical space may be found in the construction of the Gabčíkovo barrage system in the Slovak Republic (Holčík, 2001), the so-called System of Waterworks on the Danube (SWD). Upon completion of SWD, the course of the Danube was diverted into a sealed artificial navigation canal which prevents water infiltration into the subsoil, while the original riverbed is fed only the remaining water which is not used for the canal. Prior to the construction of SWD, floodplain forest ecosystems of the Danube formed an inland river delta with a branchedout river system, where a dynamic communication between the main channel, its lateral branches and the inundation area took place under the conditions unaffected by hydraulic engineering works. After the construction of SWD, however, the original landscape ecosystem of the Danube inland river delta has been gradually disappearing. In total, the change in hydrological regime due to SWD affects over $1,000 \mathrm{~km}^{2}$ of river alluvium (Oszlányi, 1999). The entire belt of drained land spanning some $250 \mathrm{~m}$ along the old Danube is in a critical ecological situation as well. It is becoming apparent that simulated artificial irrigation has succeeded in preventing the predicted massive forest dieback to a certain extent so far (Oszlányi, 2000).

Naturally, when assessing major investment projects, the precautionary principle needs to be applied due to the fact that input data for environmental landscape analyses tend to contain a certain degree of uncertainty. Application of the precautionary principle seems to be warranted in this case, as the sheer scope of landscape impact, the estimated degree of environmental damage and required investment costs make the DOE project unprecedented in the context of the Czech Republic. The potential construction of the DOE Canal would probably be the most extensive and the most expensive development project in the history of the Czech Republic with a significant environmental impact. The DOE Canal route is situated in the landscape of large Central European river alluvia, which require rehabilitation of their ecosystem functions, particularly in the context of the expected consequences of climate change.

\section{Conclusions}

The results of this paper show that some environmental aspects of the planned DOE Canal may be assessed using GIS analysis of the available data. A synthesis of the results presented here has shown that some potential environmental impacts of the DOE Canal on the landscape may be at least preliminarily quantified and objectified.

The hydrological impact of the DOE Canal will affect a total of $1,975.4 \mathrm{~km}^{2}$ of river basins in the Czech Republic. The DOE Canal will hydrologically affect 157 sites significant from the perspective of landscape and nature conservation, 7 nature parks and 113 existing water points which are used as groundwater sources. The results show that the most significant disruption of fluvial dynamics of the stream sediment regime would occur in the Protected Landscape Area of Litovelské Pomoraví. The results obtained are discussed in the context of known analogies from the Central European geographical space.

The issue of restoring the ecosystem functions of large river alluvia in the Czech Republic could be addressed, for example in a specialized landscape plan for the Morava, Oder and Elbe river floodplains, which might simultaneously be used as a reference for assessments of other plans related to the DOE Canal project.

\section{References:}

BARTOŠ, J. (2004): Historické varianty spojení řek Odry, Labe a Dunaje. In: Bartoš, M. [ed.]: Vodní cesta D-O-L. Sborník ze semináře DOL - Historie, ekologie, krajina. (pp. 7-38). Olomouc, Univerzita Palackého v Olomouci.

BIČÍK, I., JELEČEK, L., KABRDA, J., KUPKOVÁ, L., LIPSKÝ, Z., MAREŠ, P., ŠEFRNA, L., ŠTYCH, P., WINKLEROVÁ, J. (2010): Vývoj využití ploch v Česku. Praha, Česká geografická společnost.

BREN, L. J. (1993): Riparian zone, stream, and floodplain issues: a review. Journal of Hydrology, 150(2): 277-299.

BRIDGE, J. S. (2003): Rivers and Floodplains. Oxford, Blackwells. 
BUČEK, A. (2005): Vliv vodní cesty Dunaj-Odra-Labe na krajinu. In: Herber, V. [ed.]: Fyzickogeografický sborník 3 (pp. 43-48). Brno, Masarykova univerzita.

BUČEK, A., KŘÍŽ, H. [eds.] (1989): Geografické posouzení vlivu navrhované vodní cesty Dunaj-Ostrava na krajinu a životní prostředí. Brno, Geografický ústav ČSAV Brno.

BUČEK, A., MACHAR, I. (2012): Applications of landscape ecology in the assessment of anthropogenic impacts on the landscape. Olomouc, Univerzita Palackého v Olomouci.

BURROUGH, P. A., McDONNEL, R. A. (1998): Principles of Geographical Information Systems. Oxford, OUP.

CULEK, M. [ed.] (1996): Biogeografické členění České republiky. Praha: Enigma.

DEMEK, J., MACKOVČIN, P. [eds.] (2006): Hory a nížiny. Zeměpisný lexikon ČR. Praha: AOPK ČR.

DVOŘÁK, V., HLADNÝ, J., KAŠPÁREK, L. (1997): Climate change hydrology and water resources impact and adaptation for selected river basins in the Czech Republic. Climatic Change, 36: 93-106.

EISELTOVÁ, M., BIGGS, J. (1995): Restoration of stream ecosystems - an integrated catchment approach. Slimbridge, IWRB.

European Communities (2002): Assessment of plans and projects affecting Natura 2000 sites. Luxembourg, Office for Official Publications of EC.

European Commission (2003): Priority projects for the TransEuropean Transport Network up to 2020. Luxembourg, Directorate-General for Energy and Transport.

FISCHER, T. B. (2007): Theory and Practice of Strategic Environmental Assessment. London, Earthscan.

GLASSON, J., THERIVEL, R., CHADWICK, A. (2005): Introduction to Environmental Impact Assessment. London, Routledge.

HASIK, O. (2008): Environmental solutions for water transport planning in the Moravian-silesian region in the Czech Republic. In: Cygas, D., Froehner, K.D. [eds.]: $7^{\text {th }}$ Int. Conference Environmental Engineering (pp. 550-556). Vilnius, Lithunian Academy Sciences.

HASLAM, S. M. (2008): The riverscape and the river. Cambridge, Cambridge Univ. Press.

HOLČÍK, J. (2001): The impact of stream regulations upon the fish fauna and measures to prevent it. Ekológia (Bratislava), 20: 250-262.

Hydroprojekt (1968): Průplavní spojení Dunaj-Odra-Labe, generální řešení. Studie. Praha.

JONES, J. B., MULHOLAND, P. J. [eds.] (2000): Streams and groundwaters. San Diego, Academic Press.

JONGMAN, R. H. G. (1995): Nature conservation planning in Europe: developing ecological networks. Landscape and Urban Planning, 32: 169-183.

KIRCHNER, K., IVAN, A. (1999): Anastomózní říční systém v CHKO Litovelské Pomoraví. Geologické výzkumy na Moravě a ve Slezsku VI: 19-20.

KLIMO, E., HAGER, H. [eds.] (2001): The floodplain forests in Europe: current situation and perspectives. Leiden: European Forest Institute Research.

KLIMO, E., HAGER, H., MACHAR, I., BUČEK, A., SCHMALFUS, R. (2008): Revitalization and protection of floodplain forests. In: Klimo, E. et al. [eds.]: Floodplain Forests of the Temperate Zone of Europe. Lesnická práce (pp. 301-323). Kostelec nad Černými lesy.

KOLEJKA, J., POKORNÝ, J. (2000): Krajinné plánování a GIS. Př́iprava podkladů pro územní plán obce. GeoInfo, 7(3): $12-16$.

KUBEC, J. (2002): Navrhované parametry vodní cesty Dunaj-Odra-Labe a splavnost řek, které má propojit. Vodní cesty a plavba, 18(4): 33-44.

KUBEC, J., PODZIMEK, J. (1988): Svět vodních cest. Praha, Nakladatelství dopravy a spojů.

KULHAVÝ, J., SÁŇKA M. (2009): Soils at the Vrapac NNR. In: Machar, I. et al. [eds.]: History, Biodiversity and Management of Floodplain Forests (Case study of national Nature Reserve Vrapac, Czech Republic) (pp. 41-48). Olomouc, Univerzita Palackého.

LÖW, J., MíCHAL, I. (2003): Krajinný ráz. Kostelec nad Černými Lesy, Lesnická práce.

MADĚRA, P. (2001): Effect of water regime changes on the diversity of plant communities in floodplain forests. Ekológia (Bratislava), 20 (Suppl. 1): 116-129.

MACHAR, I. (2010a): Aplikace konceptu oceňování biotopů v krajině při hodnocení projektu vodního kanálu DOL. Urbanismus a územní rozvoj 13(4): 19-22.

MACHAR, I. (2010c): The influence of the Danube-Odra-Elbe water canal project on the geobiocenoses of floodplain forests (Czech Republic). Acta Universitatis Agriculturae et Silviculturae Mendelinae Brunensis, LVIII(4): 1-10.

MACHAR, I. (2012): Applying landscape ecology in conservation and management of the floodplain forest (Czech Republic). Olomouc, Univerzita Palackého.

MACHAR, I., PECHANEC, V. (2011): Application of geoecological concept of the alluvial landscape in the creation of nature reserve (Case study from Czech Republic). Acta Universitatis Agriculturae et Silviculturae Mendelinae Brunensis, 16(3): 123-134.

MACKLIN, M. G., LEWIN, J. (1997): Channel, Floodplain and Drainage Basin Response to Environmental Change. In. Thorne, C. R., Newson, M. D. [eds.]: Applied Fluvial Geomorphology for River Engineering and Management (pp. 54-69). Chichester, John Willey \& Sons.

MOLEN, D. T., van der BUIJSE, A. D. (2007): Benefits of lowland river-floodplain rehabilitation. In: Trémoliéres, M., Schnitzler, A. [eds.]: Floodplain protection, Restoration, Management (pp. 201-211). Paris, Lavoisier SAS.

NOŽIČKA, J. (1957): Projekty spojení Dunaje, Odry a Labe. Rozpravy Národního technického muzea v Praze, 6: 25-29.

OBRDLÍK, P., MACHAR, I. [eds.] (2005): Závěrečná zpráva o řešení projektu VaV2003/610/02/03 Krajinně ekologické, vodohospodářské, ekonomické a legislativní hodnocení záměru výstavby kanálu Dunaj-Odra-Labe. Praha, MŽP ČR.

OSZLÁNYI, J. (1999): Consequences of anthropic impact on Danube floodplain forests in Slovakia. Ekológia (Bratislava), 18(Suppl. 1): 103-110.

OSZLÁNYI, J. (2000): Forestry-managerial measurements in the context of landscape-ecological planning in the Danube river inundation. Ekológia (Bratislava), 19(Suppl. 2): 112-117. 
PECHANEC, V. (2012): GIS v ochraně př́rody. In: Machar, I., Drobilová, L. [eds.]: Ochrana přírody a krajiny v České republice (pp. 738-750). Olomouc, Univerzita Palackého.

PEDROLI, B. (1999): The Nature of Lowland Rivers: a Search for River Identity. In: Wiens, J.A., Moss, R. [eds.]: Issues in Landscape Ecology. Proceedings from $5^{\text {th }}$ World Congresss of IALE (pp. 103-111). Snowmass Village, Colorado, University of Guelph.

PENKA, M., VYSKOT, M., KLIMO, E., VAŠÍČEK, F. (1985): Floodplain Forest Ecosystem I. Before Water Management Measures. Praha, Academia.

PENKA, M., VYSKOT, M., KLIMO, E., VAŠÍČEK, F. (1991): Floodplain Forest Ecosystem II. After Water Management Measures. Praha, Academia.

PETRÁŠOVÁ, T., MACHALÍKOVÁ, P. (2013): A Rich Network of Waterways as the 'Panacea' of the Cislethanian Society? In: $32^{\text {nd }}$ Symposium on the Issue of the $19^{\text {th }}$ Plzeň Century (pp. 32-42). Plzeň, Západočeská univerzita.

PITHART, D., KŘOVÁKOVÁ, K. (2012): Ekosystémové funkce a služby říčních niv. In: Pithart, D. et al. [eds.]: Význam retence vody v ř́čních nivách (pp. 101-108). České Budějovice, Daphne ČR.

PLESNÍK, J. (2012): Ecosystem Ecology Contribution for Conservation Biology. In: Machar, I., Drobilová, L. [eds.]: Ochrana přírody a krajiny v České republice (pp. 13-21). Vol. I. Olomouc, Palacký University.

POLÁČEK, L. (1999): Prehistory and history of floodplain. In: Šeffer, J., Stanová, V. [eds.]: Morava River Floodplain Meadows - Importace, Restoration and Management (pp. 26-36). Bratislava, Daphne.

PRAX, A., RICHTER, W., ČERMÁK, J., HYBLER, V. (2008): The hydrological and moisture regime of soils in floodplain forests. In: Klimo E. et al. [eds.]: Floodplain Forests of the Temperate Zone of Europe: Lesnická práce (pp. 75-101). Kostelec nad Černými lesy.

ROSGEN, D. (1996): Applied River Morphology. Colorado Pagosa Springs, Parelli University.

ROTH, P. (2003): Legislativa Evropských společenství v oblasti územní a druhové ochrany přírody. Praha, MŽP ČR.
SALAŠOVÁ, A. (2012): Krajina v ČR v rámci Evropské úmluvy o krajině. In: Machar, I., Drobilová, L. [eds.]: Ochrana př́rody a krajiny v České republice (pp. 116-128). Olomouc, Univerzita Palackého.

SEJÁK, J., POKORNÝ, J. (2008): Oceňování ekosystémových služeb na příkladu říční nivy. In. Pithart, D. et al. [eds.]: Ekosystémové služby říční nivy (pp. 183-190). Třeboň, Ústav systémové biologie a ekologie AV ČR.

SKLENIČKA, P. (2003): Základy krajinného plánování. Praha, Vydavatelství Naděžda Skleničková.

ŠRÁM, R. (2014): Stanovisko Komise pro životní prostředí AV ČR k projektu kanálu Dunaj-Odra-Labe z února 2014 [online]. [cit. 23.03.2014] Accessible at: http://www. cas.cz/press/sys/galerie-download/140227-TZ-avcr-kzpkanal-labe-odra-dunaj-zaporne-stanovisko.pdf

ŠTĚRBA, O. (2004): ̌́íční doprava a její ekologické problémy. In: Bartoš, M. [ed.]: Vodní cesta D-O-L. Sborník ze semináře DOL - Historie, ekologie, Krajina (pp. 47-52). Olomouc, Univerzita Palackého v Olomouci.

ŠTĚRBA, O., MĚKOTOVÁ, J., BEDNÁŘ, M., KILIÁNOVÁ, H., SAMSONOVÁ, P. (2000): Obnova ekologického kontinua krajiny řeky Moravy. Vodní hospodářství, 50(7): 141-144.

ŠTĚRBA, O. [ed.] (2008): Říční krajina a její ekosystémy. Olomouc, Univerzita Palackého.

TOURNAYE, C., PAULI, G., SAHA, D. M., VAN DER WERF, H. (2010): Current issues of inland water transport in Europe. Proceedings of the institution of civil engineers, 163(5): 19-28.

VALETT, H. M., HAUER, F. R., STANFORD, J. A. (2014): Landscape Influences on Ecosystem Function: Local and Routing Control of Oxygen Dynamics in a Floodplain Aquifer. Ecosystems, 17(2): 195-211.

VLČEK, V. [ed.] (1992): Ekologicko - technická studie vodních cest ČR (výsledky základního a aplikovaného geografického výzkumu). Brno, Geografický ústav ČSAV.

YAFFEE, S. L. (1999): Three faces of ecosystem management. Conservation Biology, 13: 713-725.

ZINKE, J. (2002): Gabcikovo: 10 years after the conflict. Danube Watch (Vienna), 6(2): 14-15.

Initial submission 1 July 2014, final acceptance 22 February 2015

Please cite this article as:

MACHAR, I., KIRCHNER, K., PECHANEC, V., BRUS, J., KILIÁNOVÁ, H., ŠÁLEK, L., BUČEK, A. (2015): Potential geo-ecological impacts of the proposed Danube-Oder-Elbe Canal on alluvial landscapes in the Czech Republic. Moravian Geographical Reports, 23(2): 38-46. DOI: $10.1515 /$ mgr-2015-0009 